\title{
Mulching Options for Northwest Organic and Conventional Orchards
}

\author{
David Granatstein ${ }^{1}$ \\ Center for Sustaining Agriculture and Natural Resources, Washington State University, Wenatchee, WA 98801 \\ Kent Mullinix \\ Institute for Sustainable Horticulture, Kwantlen University College, Surrey, BC V3W 2M8, Canada
}

Additional index words. orchard floor management, weed control, water conservation, soil quality, nitrogen

\begin{abstract}
The semiarid climate of the Pacific Northwest allows for the production of organic, temperate tree fruit relatively free of disease and with fewer key insect pests compared with other regions of the United States. Weed control and soil fertility are two of the higher cost areas for organic tree fruit where alternatives are being sought through research and on-farm innovation. Mulches, both living [e.g., white clover [(Trifolium repens)] and inert (e.g., wood chips) show promise for controlling weeds, conserving water, providing nitrogen $(N)$, or improving tree growth, but potentially have system trade-offs such as increased rodent pests and unwanted late-season N. Growers need orchard floor management practices that help them maintain or improve soil quality per the requirements of the National Organic Standards.
\end{abstract}

The Pacific Northwest is a leading national producer of organic temperate tree fruits \{particularly apple [Malus $\times$ sylvestris (L.) Mill. var. domestica (Borkh.) Mansf.], pear [Pyrus communis], and cherry [Prunus avium] $\}$ because of the relative absence of pests and diseases in the commercial production zone (semiarid, irrigated, winter precipitation). Production began to expand rapidly in the mid 1990s with the introduction of pheromone mating disruption for control of codling moth (Cydia pomonella), the key insect pest of apple and a serious pear pest. Production leveled off in 2000, when prices for organic apples and pears declined (Granatstein et al., 2006). Production is expanding again, with large retailers such as Wal-Mart and Costco increasing their orders to meet growing consumer demand, and may saturate demand and depress prices (M. Miles, pers. comm.). Thus, organic growers seek ways to cut production costs in light of uncertain price premiums in the future.

Based on previous organic tree fruit grower surveys, the three top production issues identified for Washington were crop load management, weed control, and soil fertility (Cornwoman and Granatstein, 1994; Granatstein, 2003). The latter two management areas generally entail significantly higher costs than in conventional systems, for which relatively inexpensive chemical herbicides and fertilizers are readily available. In addition, the National Organic Standards require that organic growers maintain or improve soil quality. Practices such as tillage for weed control can degrade soil

\footnotetext{
We thank the Washington Tree Fruit Research Commission for partial funding support.

Collaboration and technical support was provided by E. Hogue, G. Neilsen, S. Kuchta, T. Forge, E. Kupferman, A. Kukes, E. Kirby, R. Barnhart, L. VanWechel, P. Dauer, L. Garcia, and F. Sarmiento. Thanks to Wenatchee Valley College for hosting these projects at their orchard and to Simplot Soilbuilders for the use of the Enviroscan system. ${ }^{1}$ To whom reprint requests should be addressed; e-mail granats@wsu.edu.
}

quality (Cambardella and Elliott, 1993; Fiscus and Neher, 2002; Six et al., 1998), and alternative methods are needed. Tree fruit production in the region relies on irrigation water from mountain snowpack, and the effect of climate change on water supply resulting from thinner snowpack and earlier snowmelt is anticipated to affect growers (Bauman et al., 2006). Strategies for conserving water, including mulching and other orchard floor management techniques, will become increasingly important for long-term sustainability.

Organic orchards require adequate weed control for the same reasons as conventional orchards: to minimize competition for nutrients and water; to provide acceptable tree growth, high fruit yield, and large fruit size; and to reduce habitat for rodents [e.g., voles (Microtus spp.)] that can damage or kill trees (Hogue and Neilsen, 1987; Merwin and Ray, 1997). Organic orchardists do have a variety of weed control strategies and tools to draw upon (Table 1). These include tillage, flaming, and other thermal techniques; inert mulches (e.g., wood chips, weed fabric), living mulches; organic herbicides; and allelopathy. None tend to be as effective, durable, or low cost as the herbicide strategies used in conventional orchards. For example, cultivation-based weed control cost $\$ 1050 /$ ha/year in a Yakima Valley orchard study (Glover et al., 2002), which is more than four times the cost of a typical herbicide program (two applications per season). Therefore, organic tree fruit producers in the Northwest typically draw on several options and integrate them into a strategy that may change during the course of the growing season and during the life of the orchard.

Organic $\mathrm{N}$ sources typically range in price from $\$ 3$ to $\$ 13$ per kg N (dry basis) (Granatstein, unpublished data), compared with $\$ 1$ to $\$ 2$ per $\mathrm{kg} \mathrm{N}$ for synthetic $\mathrm{N}$ fertilizer. Along with precise management of irrigation to minimize $\mathrm{N}$ leaching losses, orchard floor management practices are needed that can improve $\mathrm{N}$ cycling, conserve $\mathrm{N}$, or provide fixed $\mathrm{N}$ through legumes or associative microbial fixation.
Management options to meet these multiple goals include the use of organic mulches (hay, straw, wood chips, paper, weed fabric) that can provide weed control, soil improvement, and increased tree growth and yield (Forge et al., 2003; Neilsen et al., 2003; Oliveira and Merwin, 2001; Sanchez et al., 2003; Yao et al., 2005). Use of a vegetative cover, or "living mulch," can provide weed control, soil improvement, nutrient cycling, and $\mathrm{N}$ (if leguminous), but may compete with trees (Marsh et al., 1996; Sanchez et al., 2003; Stork and Jerie, 2003; Yao et al., 2005). Living mulches contribute root exudates and labile residues that can stimulate the soil fauna and improve nutrient cycling and retention (Rovira et al., 1990; Wardle et al., 2001) and disease control (Forge et al., 2000; Gu and Mazzola, 2003). Mulches also conserve soil moisture (Baxter, 1970) and can provide a habitat for beneficial insects (Liang and Huang, 1994; Tedders, 1983) and biological controls (Lacey et al., 2006). However, many of these options have drawbacks, such as increased rodent populations (Merwin and Ray, 1999; Sullivan and Hogue, 1987), disease (Merwin and Stiles, 1994), nutrient competition, and attraction of pests. These problems must be weighed against the potential benefits (Meyer et al., 1992).

\section{ORCHARD MULCHING MANAGEMENT TRIALS}

Given these concerns, we have conducted a series of orchard mulching trials in apple orchards with the goal of achieving multiple benefits, including weed control, $\mathrm{N}$ supply, water conservation, soil quality improvement, reduced costs, and potential biological control of pests, while promoting high fruit productivity and quality. Other orchard floor management studies are underway in various locations, and collectively these will provide organic orchardists with field-validated practices and strategies that they can incorporate into their management system. These same practices may also appeal to conventional growers in coping with potential water and fossil fuel constraints. 
Table 1. Weed control options for organic orchards: Attributes and constraints.

\begin{tabular}{|c|c|c|}
\hline & Attribute & Constraint \\
\hline \multirow[t]{3}{*}{ Tillage } & Effective & $\begin{array}{l}\text { Can degrade soil quality, organic } \\
\text { matter depletion }\end{array}$ \\
\hline & Reduces rodent habitat & Costly in young orchards \\
\hline & & $\begin{array}{l}\text { Can damage roots and trunks, } \\
\text { irrigation system }\end{array}$ \\
\hline \multirow[t]{4}{*}{ Flaming } & Can control weeds around trunk & Potential tree injury \\
\hline & Reduces rodent habitat & Not good for older weeds, perennials \\
\hline & & Uses fossil fuels \\
\hline & & Irrigation system damage \\
\hline \multirow[t]{3}{*}{ Inert mulches } & Effective for most weeds & Costly to apply \\
\hline & Can improve soil quality & Can tie up $\mathrm{N}$ \\
\hline & Conserves moisture & May be hard to source \\
\hline \multirow[t]{4}{*}{ Living mulches } & Add biodiversity & Compete with trees \\
\hline & Benefit soil quality & Rodent habitat \\
\hline & Legumes can fix $\mathrm{N}$ & Variable persistence \\
\hline & Theoretically low maintenance & Variable ability to compete with weeds \\
\hline \multirow[t]{4}{*}{ Organic herbicides } & Can control weeds around trunk & Expensive \\
\hline & No physical damage to tree, roots & Inconsistent effectiveness \\
\hline & Reduces rodent habitat & May need many applications \\
\hline & & Few registered products \\
\hline
\end{tabular}

The trials have taken place on research centers and commercial orchards in the Columbia River Valley region of central Washington State and the Okanagan Valley of British Columbia, Canada. This is a semiarid region that requires irrigation for fruit production, with an annual precipitation of 150 to $400 \mathrm{~mm}$ that occurs in a xeric moisture regime. Soils are generally low in organic matter and available N, B, and Zn. Perennial grass is typically planted in the tree alley, and most conventional orchards use herbicides to keep a 1.5 - to 2 -m-wide weed-free strip in the tree row. Vegetative competition with young trees has been shown to reduce growth and early fruit yield (Hogue and Neilsen, 1987), and grower experience corroborates this.

Results from two mulching trials are presented here, and reference is made to key findings from other studies. Trial 1 compared the performance of a variety of inert and living mulches for weed suppression, tree growth, fruit yield and quality, and several soil parameters. Trial 2 compared wood chip mulch and bare ground control over two seasons for the effect of mulching on irrigation water use and soil moisture depletion.

\section{MATERIALS AND METHODS}

Trials were conducted at the Wenatchee Valley College Teaching and Demonstration Orchard, East Wenatchee, WA, on a Pogue fine sandy loam (Aridic Haploxeroll), averaging $1 \%$ to $2 \%$ organic matter with a $\mathrm{pH}$ of 6.1 to 7.3 and an average annual precipitation of $215 \mathrm{~mm}$. All plots were irrigated with microjet sprinklers and received the same standard pest control. Blocks were not under organic management, but the alternative practices tested were all suitable for organic systems.

Trial 1. We applied seven mulch and living mulch treatments in a block of 'Red Delicious' on M26 rootstock (established 1995; $1 \times 4.3-\mathrm{m}$ spacing, 2760 trees/ha). The experimental design was a randomized complete block, with five replications. Plots consisted of five sample trees and a guard tree on each side. The following treatments were imposed on the 1.6-m-wide weed-free tree row: CTL, control (bare ground); WCM, yard waste wood chip mulch (10 cm depth, 88.8 $\mathrm{kg} \cdot \mathrm{m}^{-2}$ ); SPM, shredded paper mulch (white office, $10 \mathrm{~cm}$ depth, loose); ALM, chopped alfalfa hay mulch (Medicago sativa L.) (10 $\mathrm{cm}$ depth, $39.8 \mathrm{~kg} \cdot \mathrm{m}^{-2}$ ); MUS, oriental mustard (Brassica juncea L. cv. Pacific Gold); $\mathrm{RYE}$, winter rye (Secale cereale L. cv. Wheeler); CLM, dwarf New Zealand white clover (Trifolium repens L.), mowed; and CLF, dwarf New Zealand white clover (Trifolium repens $\mathrm{L}$.), flamed. The WCM, SPM, and ALM treatments were applied on 27 May 1999. Mustard and clover were planted on 17 Aug. 1999 and rye on 31 Aug. 1999. Shredded paper was renewed annually in early May, and wood chips were renewed once in May 2002 (season 3 of the study). Trees were fertilized with ammonium nitrate $(34 \% \mathrm{~N})$ as follows: May 1999, $0.05 \mathrm{~kg} /$ tree; May 2000 , $0.05 \mathrm{~kg} /$ tree; Oct. 2000, $0.1 \mathrm{~kg} /$ tree (except clover); Oct. 2001, $0.1 \mathrm{~kg} /$ tree.

Trunk cross-sectional area was calculated from trunk circumference measured $20 \mathrm{~cm}$ above the graft union in May 1999 and each October thereafter. Weeds were monitored with three random samples per plot using a $0.25-\mathrm{m}^{2}$ hoop, visually estimating percent cover, counting grass and broadleaf weeds, and measuring dry biomass (limited sammidshoot leaves collected around July 20, washed, dried and ground, and analyzed by combustion on a Leco C-N Analyzer (Leco Co., St. Joseph, MI). Leaf greenness was measured with a SPAD-502 chlorophyll meter (Minolta Camera Co., Osaka Japan), sampling 30 midterminal leaves per plot. Tree senescence was evaluated qualitatively on a visual scale of 1 to 5 points, with 1 point equal to all yellow leaves and 5 points equal to all green leaves. Fruit firmness was measured with a Guss Fruit Texture Analyzer (Strand, South Africa). Fruit color was estimated visually by a trained technician. pling). Leaf percent $\mathrm{N}$ was measured from
Soil moisture was monitored (unreplicated) using tensiometers (Soil Moisture, Santa Barbara, CA) placed at depths of 10 $\mathrm{cm}$ and $30 \mathrm{~cm}$ in the CTL, WCM, and CLM plots. Readings were taken 4 to $5 \mathrm{~d} /$ week from early May through July. Soil organic matter was measured by Loss on Ignition using a muffle furnace at $400{ }^{\circ} \mathrm{C}$ for $16 \mathrm{~h}$ after heating of the crucibles and oven-drying soil at $105{ }^{\circ} \mathrm{C}$ for $24 \mathrm{~h}$. Water infiltration was measured with a single-ring infiltrometer penetrating $10 \mathrm{~cm}$ into the soil. An initial infiltration was made to wet the soil. An hour later, when the soil was at field capacity, the measurement was made by "ponding" 2.5 $\mathrm{cm}$ of water in the ring and timing its disappearance. Soil temperature was measured with a dial analog thermometer, with readings taken at a $5-\mathrm{cm}$ depth on the west side of each tree row.

Soil faunal analyses were conducted by $\mathrm{T}$. Forge, Agriculture and AgriFood Canada, Summerland, BC, using methods described in Forge et al., (2003).

Trial 2. A soil moisture trial was established in June 2000 in a block of 'Gala' on M26 rootstock (established 1997, 1.2 × $4.3 \mathrm{~m}$ spacing, 2370 trees/ha). Experimental design was a randomized complete block, with four replications. Plots were entire rows (15-35 m long). Treatments were control (U, unmulched; glyphosate weed control, two times per year; $1.5 \%$ a.i. applied at 234 $\left.\mathrm{L} \cdot \mathrm{ha}^{-1}\right)$, and wood chip mulch (M, 10-cm depth, as per trial 1). An Enviroscan soil moisture monitoring system was installed (Sentek Sensor Technologies, Stepney, Australia), with one probe in each plot. Each probe had a sensor at a depth of 10, 20, 30, and $50 \mathrm{~cm}$. Readings were taken every 30 min, recorded on a data logger, and then downloaded to a laptop computer with the dedicated software. In 2000, all plots received the same irrigation, based on need in the driest treatment. In 2001, each treatment was watered independently, based on the refill point indicated in the software.

Data were analyzed using analysis of variance and Fisher's LSD (SAS Institute, Cary, NC).

\section{RESULTS}

At the beginning of trial 1, weed pressure in the plots was moderate as a result of past years of herbicide control. Annual grass weeds such as green foxtail (Setaria viridis) and downy brome (Bromus tectorum) did increase rapidly during the course of the trial. Overall, the SPM, WCM, and white clover treatments provided good weed control (Table 2), and suppression of grass and broadleaf weeds was similar. The ALM plots were often most weedy, because any weed seeds on or in the mulch found an excellent germination and growth medium. Annual grass weeds infested the fall-planted mustard plots in 2000 and 2001. Winter rye was effective for one season (2000), especially in suppressing grassy weeds. In Winter 2002, the clover was severely damaged (eaten) by rodents, and it did not compete 
Table 2. Weed percent cover in tree row (July), Trial 1.

\begin{tabular}{lccr}
\hline & \multicolumn{3}{c}{ Weed \% Cover } \\
\cline { 2 - 4 } Treatment & 2000 & 2001 & 2002 \\
\hline CTL & $46 \mathrm{a}^{\mathrm{z}}$ & $16 \mathrm{~b}$ & $61 \mathrm{a}$ \\
WCM & $3 \mathrm{~b}$ & $3 \mathrm{bc}$ & $1 \mathrm{~b}$ \\
SPM & $4 \mathrm{~b}$ & $1 \mathrm{c}$ & $1 \mathrm{~b}$ \\
ALM & $39 \mathrm{a}$ & $8 \mathrm{~b}$ & $49 \mathrm{a}$ \\
MUS & $45 \mathrm{a}$ & $69 \mathrm{a}$ & $5 \mathrm{~b}$ \\
RYE & $3 \mathrm{~b}$ & $6 \mathrm{bc}$ & $22 \mathrm{~b}$ \\
CLM & $10 \mathrm{~b}$ & $<1 \mathrm{c}$ & $9 \mathrm{~b}$ \\
CLF & n.d. & $3 \mathrm{bc}$ & $12 \mathrm{~b}$ \\
\hline
\end{tabular}

${ }^{\mathrm{z}}$ Means within years with the same letter are not significantly different $(P<0.05)$.

well with weeds after that time. The initial wood chip application provided good weed control for three seasons before needing renewal. Shredded paper formed a mat after an initial irrigation and provided excellent weed control, but degraded by the end of each growing season and required annual renewal.

Tree growth (trunk cross-sectional area) was greatest with the ALM, as a result of the high rate of $\mathrm{N}$ input $\left(\approx 300-400 \mathrm{~kg} \cdot \mathrm{ha}^{-1}\right)$ that lasted several years (Table 3). Clover plots, WCM, and SPM plots exhibited similar tree growth, suggesting non-N benefits under the high $\mathrm{C}$ materials. Tree growth was lowest in the CTL and RYE plots. Alfalfa mulch also led to the highest fruit yields, followed closely by clover plots, again suggesting an $\mathrm{N}$ response (Table 3). Yields were the same for WCM and CTL. There were no consistent effects on fruit size (data not shown). However, the treatments resulting in higher $\mathrm{N}$ did tend to affect fruit quality negatively, with lower firmness and less red color in 2000 (Table 3), and less maturity for alfalfa plots in 1999. Soluble solids and titratable acidity were unaffected. In addition, the ALM appeared to induce alternate bearing with annual fruit yields of 14.5, 27.7, 13.8 , and $24.4 \mathrm{~kg} /$ tree from 1999 to 2002 respectively.

The high $\mathrm{N}$ treatments (ALM, CLM, $\mathrm{CLF}$ ) led to clear responses in leaf $\mathrm{N}$ in the trees (Table 4). Within several weeks after application, the leaves in the ALM plots were noticeably greener, and this was confirmed by June 1999 SPAD readings of 45 for ALM trees versus 38 to 39 for WCM, SPM, and CTL. This N enrichment lasted for three crops after application. Nitrogen contribution from clover was evident in 2000, where leaf $\mathrm{N}$ in those plots was significantly greater than the control, and it increased in 2001. In a related mineralization experiment in mowed white clover living mulch, we measured up to $60 \mathrm{~kg} \cdot \mathrm{ha}^{-1} \mathrm{~N}$ release over 3 weeks that would be available to the trees (data not included).

Trees in ALM and clover plots exhibited delayed senescence relative to other treatments in Fall 2000 (Fig. 1). By Fall 2001, trees in ALM plots were senescing faster than clover plots, suggesting that the alfalfa mulch $\mathrm{N}$ contribution was waning.

In 2000, mulched plots in trial 2 consistently had $15 \%$ to $20 \%$ higher soil moisture at the end of each irrigation cycle than the
Table 3. Effect of mulches on tree growth and fruit production.

\begin{tabular}{lcccc}
\hline & $\begin{array}{c}\text { TCSA 4-yr } \\
\text { Treatment }\end{array}$ & $\begin{array}{c}\text { Fruit yield 3-year } \\
\text { cum. }(\mathrm{kg} / \text { tree })\end{array}$ & Fruit firmness $(\mathrm{N})$ & Fruit color $(\%$ red) \\
\hline CTL & $59 \mathrm{c}^{\mathrm{z}}$ & $50.1 \mathrm{c}$ & $85.2 \mathrm{a}$ & $99.2 \mathrm{a}$ \\
WCM & $74 \mathrm{~b}$ & $48.0 \mathrm{c}$ & $85.2 \mathrm{a}$ & $99.3 \mathrm{a}$ \\
SPM & $72 \mathrm{~b}$ & $52.4 \mathrm{bc}$ & $84.8 \mathrm{a}$ & $99.0 \mathrm{a}$ \\
ALM & $90 \mathrm{a}$ & $66.0 \mathrm{a}$ & $77.7 \mathrm{~b}$ & $91.9 \mathrm{~b}$ \\
MUS & $70 \mathrm{~b}$ & $54.6 \mathrm{bc}$ & $83.9 \mathrm{a}$ & $98.8 \mathrm{a}$ \\
RYE & $60 \mathrm{c}$ & $52.6 \mathrm{bc}$ & $83.0 \mathrm{a}$ & $99.5 \mathrm{a}$ \\
CLM & $74 \mathrm{~b}$ & $60.8 \mathrm{ab}$ & $81.2 \mathrm{ab}$ & $98.5 \mathrm{a}$ \\
CLF & $78 \mathrm{~b}$ & $61.5 \mathrm{ab}$ & $98.4 \mathrm{a}$ \\
\hline
\end{tabular}

${ }^{2}$ Means with the same letter are not significantly different $(P<0.05)$. unmulched plots. In 2001 (the second experimental season), the two treatments were watered independently according to need, and mulching reduced cumulative irrigation application by $20 \%$ to $30 \%$ (Fig. 2). The effect was strongest in the top $10 \mathrm{~cm}$ and decreased with depth. Soil moisture in trial 1 was similar between the CTL and clover at a $10-\mathrm{cm}$ depth, but clover had consistently higher soil moisture at a $30-\mathrm{cm}$ depth (data not shown). Wood chip plots had the highest moisture at a $10-\mathrm{cm}$ depth and were similar to clover at a $30-\mathrm{cm}$ depth.

There were no significant effects of treatment on soil organic matter or bulk density (Table 5.) Alfalfa, SPM, and WCM mulch tended to increase water infiltration rates compared with the control and other treatments. Soil temperatures in spring $(5-\mathrm{cm}$ depth) warmed quickest in the control, slowest with SPM, and intermediate for WCM, RYE, and clover. This had a minimal effect on bloom development.

An assessment of the soil microfauna in June 2000 predicted enhanced $\mathrm{N}$ mineralization under the ALM and clover (Fig. 3). This was generally associated with increased populations of bacterivorous nematodes and, to a lesser extent, with protozoa. Control plots had the lowest numbers of these organisms and of mycophagus nematodes. Numbers of root lesion nematode (Pratylenchus penetrans) were similar in the CTL, clover, and MUS plots, whereas none were found
Table 4. Effect of mulches on tree leaf $\mathrm{N}$.

\begin{tabular}{lccl}
\hline & \multicolumn{3}{c}{ Leaf total N (\%) } \\
\cline { 2 - 4 } Treatment & 1999 & 2000 & 2001 \\
\hline CTL & $2.0 \mathrm{~b}^{z}$ & $2.0 \mathrm{~d}$ & $1.8 \mathrm{de}$ \\
WCM & $2.0 \mathrm{~b}$ & $1.9 \mathrm{de}$ & $1.8 \mathrm{e}$ \\
SPM & $2.0 \mathrm{~b}$ & $2.0 \mathrm{de}$ & $1.8 \mathrm{e}$ \\
ALM & $2.8 \mathrm{a}$ & $2.5 \mathrm{a}$ & $2.2 \mathrm{bc}$ \\
MUS & n.d. & $2.1 \mathrm{~cd}$ & $2.0 \mathrm{~cd}$ \\
RYE & n.d. & $1.8 \mathrm{e}$ & $2.1 \mathrm{c}$ \\
CLM & n.d. & $2.2 \mathrm{bc}$ & $2.5 \mathrm{a}$ \\
CLF & n.d. & $2.3 \mathrm{~b}$ & $2.4 \mathrm{ab}$ \\
\hline
\end{tabular}

${ }^{\mathrm{z}}$ Means within year with the same letter are not significantly different $(P<0.05)$.

under RYE [consistent with Forge et al. (2000)].

\section{DISCUSSION}

Mulching is a traditional practice used in horticultural crop production, gardening, and landscaping to control weeds and conserve moisture. It has not been widely used in tree crops, given its greater expense (Merwin, 1995) compared with herbicides, and problems with plastic film or fabric mulching allowing weed escapes around trunks and seams. Merwin and Stiles (1994) found that a straw mulch in New York state apple orchards led to a substantial increase in young tree mortality as a result of crown rot (Phytophthora cactorum). In the semiarid fruit-producing regions of the Northwest,

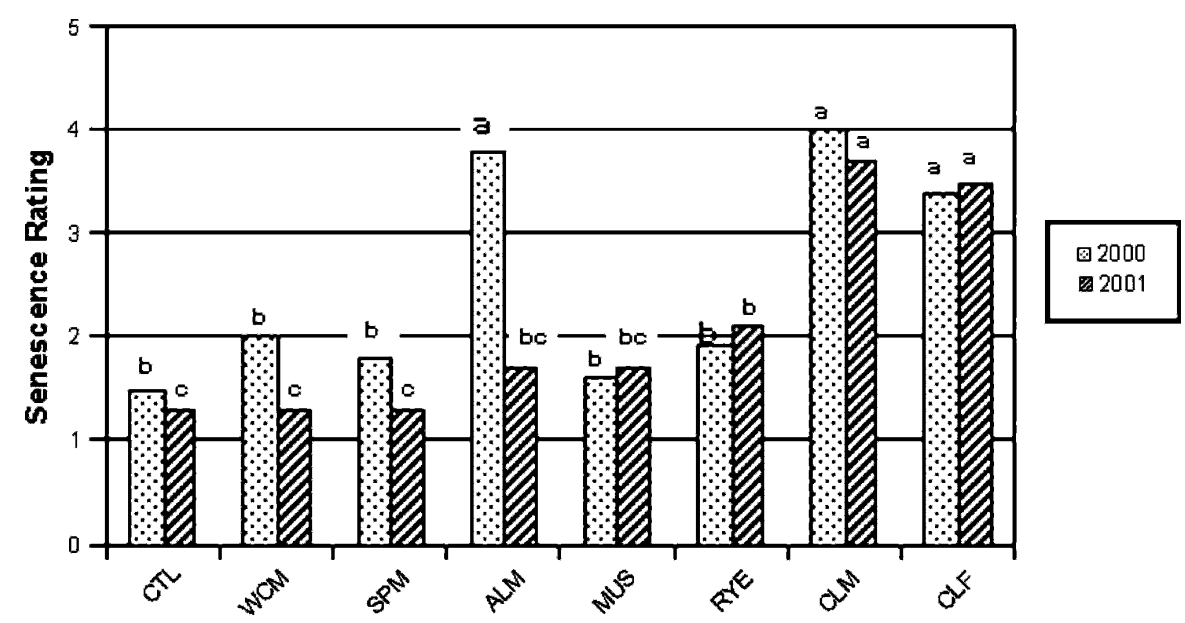

Fig. 1. Qualitative rating of tree senescence, October (1 pt, all leaves yellow; 5 pt, all leaves green). Means within year with the same letter are not significantly different $(P<0.05)$. 


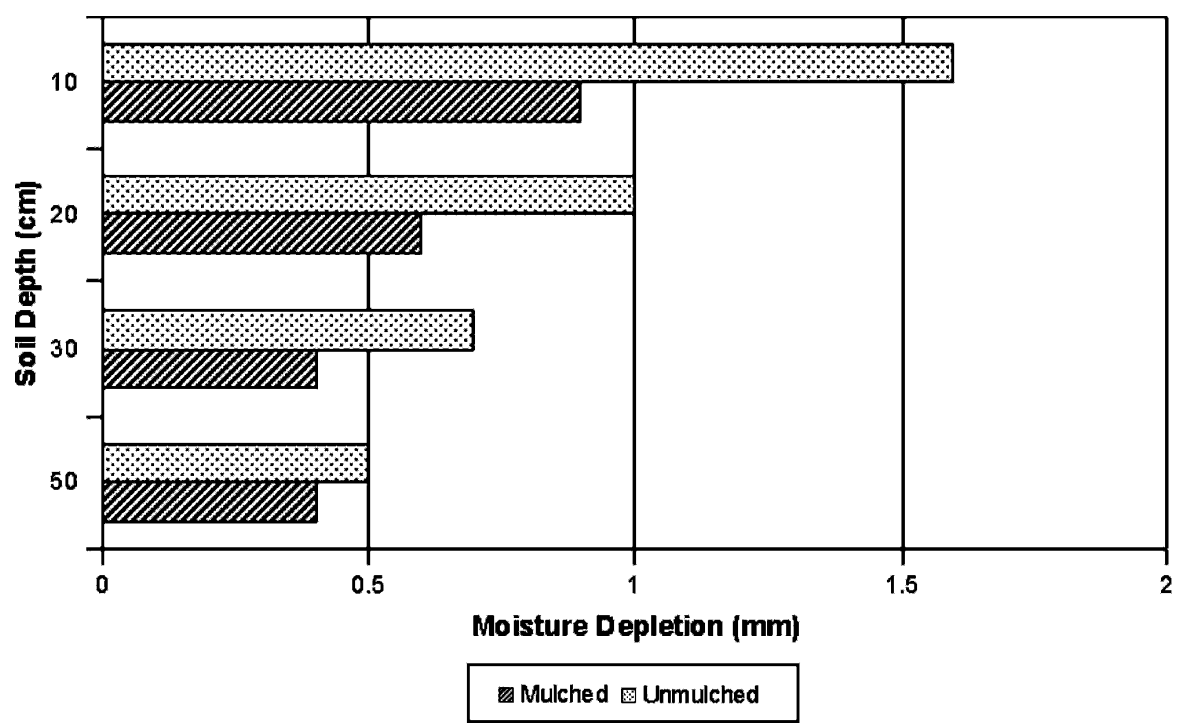

Fig. 2. Average daily soil moisture depletion under mulched and unmulched trees (July-Aug. 2001, trial 2). Means are significantly different $(P<0.05)$ at 10,20 , and $30 \mathrm{~cm}$ depth.

Table 5. Effect of mulches on soil properties. ${ }^{2}$

\begin{tabular}{lcccc}
\hline Treatment & Organic matter $(\%)$ & $\begin{array}{c}\text { Bulk density } \\
\left(\mathrm{g} \cdot \mathrm{cm}^{-2}\right)\end{array}$ & $\begin{array}{c}\text { Water infiltration } \\
\left(\mathrm{cm} \cdot \mathrm{min}^{-1}\right)\end{array}$ & $\begin{array}{c}\text { Soil temperature } \\
\text { at } 5 \mathrm{~cm}\left({ }^{\circ} \mathrm{C}\right)\end{array}$ \\
\hline CTL & $1.56 \mathrm{a}^{y}$ & $1.38 \mathrm{a}$ & $1.35 \mathrm{abc}$ & $20.8 \mathrm{a}$ \\
WCM & $1.47 \mathrm{a}$ & $1.37 \mathrm{a}$ & $2.47 \mathrm{~cd}$ & $16.1 \mathrm{de}$ \\
SPM & $1.66 \mathrm{a}$ & $1.36 \mathrm{a}$ & $3.26 \mathrm{~d}$ & $14.1 \mathrm{f}$ \\
ALM & $1.63 \mathrm{a}$ & $1.40 \mathrm{a}$ & $2.49 \mathrm{~cd}$ & $17.7 \mathrm{bc}$ \\
MUS & $1.62 \mathrm{a}$ & $1.30 \mathrm{a}$ & $0.97 \mathrm{a}$ & $18.3 \mathrm{~b}$ \\
RYE & $1.86 \mathrm{a}$ & $1.32 \mathrm{a}$ & $1.17 \mathrm{ab}$ & $15.3 \mathrm{e}$ \\
CLM & $1.82 \mathrm{a}$ & $1.32 \mathrm{a}$ & $1.56 \mathrm{bcd}$ & $15.3 \mathrm{e}$ \\
CLF & $1.76 \mathrm{a}$ & $1.32 \mathrm{a}$ & $1.54 \mathrm{bcd}$ & $15.5 \mathrm{e}$ \\
\hline
\end{tabular}

${ }^{\mathrm{z}}$ Organic matter measured on 12 Apr. 2001. Bulk density measured on 27 Aug. 2001. Infiltration measured on 1 Aug. 2001. Soil temperature measured on 4 May 2001.

${ }^{\mathrm{y}}$ Means with the same letter are not significantly different $(P<0.05)$.

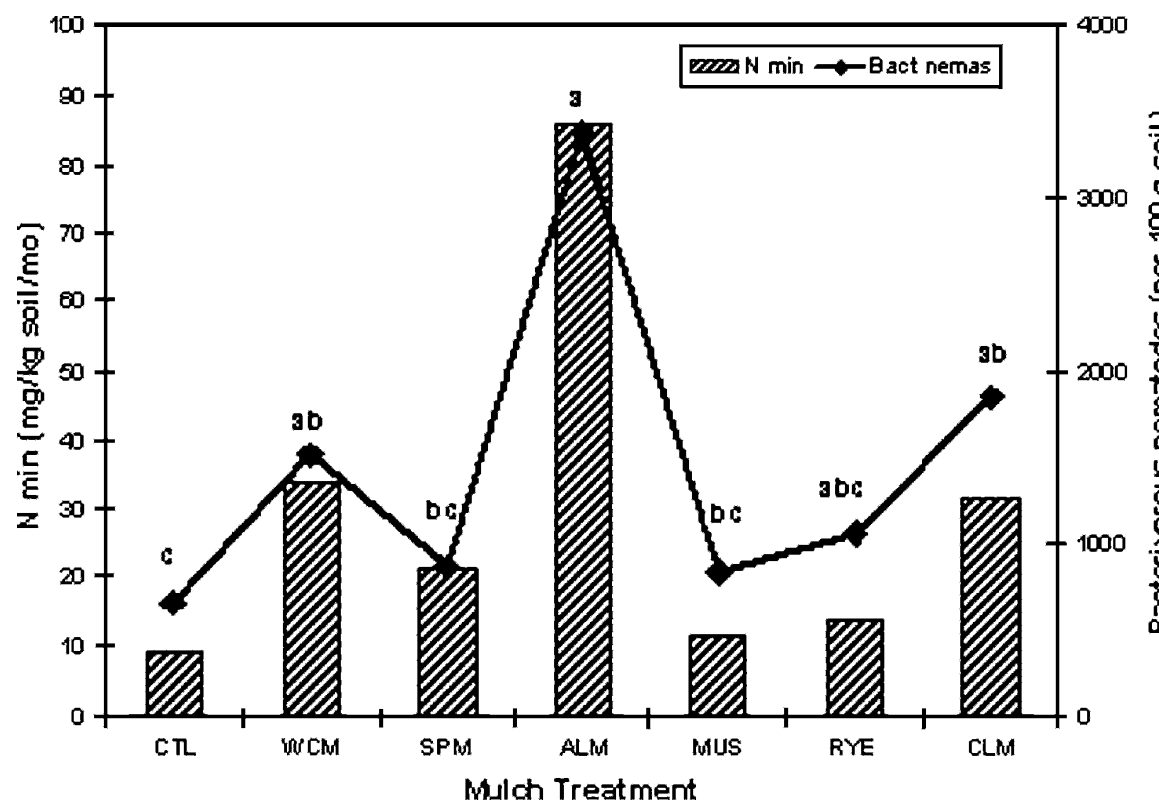

Fig. 3. Estimated $\mathrm{N}$ mineralization by soil microfauna and population of bacterivorous nematodes (June 2000). Means for nematodes with the same letter are not significantly different $(P<0.05)$.

mulches can conserve water without causing significant disease problems. There are underused organic residuals in our agricultural areas, such as mint (Mentha spp.)
In our trial, WCM, SPM, and white clover living mulch all provided excellent weed suppression. Tree growth was also improved in WCM and SPM plots relative to the CTL, despite their high C-to-N ratio and their likelihood to immobilize applied $\mathrm{N}$. This may be the result of improved physical conditions for tree roots (e.g., more stable moisture content, more favorable temperature range). Extensive new feeder root development was evident near the surface in the mulch by trees in the WCM plots. Tree growth in RYE plots was similar to the CTL, with the rye cover crop acting as an aggressive soil $\mathrm{N}$ scavenger.

Wood chips led to a $20 \%$ to $30 \%$ savings in irrigation water, whereas clover did not increase soil water depletion relative to the control and also contributed $\mathrm{N}$ to the trees. Clover is a preferred food source for voles (Thompson, 1965), and their feeding eliminated the clover stand by the third year. However, they did not damage the trees. Alfalfa hay mulch led to the greatest tree growth as a result of the high input of $\mathrm{N}$ that lasted over three seasons. This had negative effects on fruit quality and it delayed tree senescence in the fall, which could increase the risk of winter injury. Planting an $\mathrm{N}$ scavenger such as rye could counteract this problem and conserve more $\mathrm{N}$ over winter.

A living mulch in the tree row is an attractive strategy, especially for an established orchard. It can fill the tree row niche and exclude weeds, support greater soil biology through its roots exudates (F. Weibel, unpublished data), fix $\mathrm{N}$ if it is a legume, and possibly provide a habitat for beneficial insects. Planting seed once every few years is typically less costly than hauling in and placing tons of mulch material. More research is needed to identify species that compete minimally with the trees and that do not attract pests such as Lygus or voles (Meyer et al., 1992). The Swiss "Sandwich" system uses a narrow band of perennial vegetation in the trunk line combined with shallow tillage on each side of the trees (Sanchez et al., 2003; Schmid et al., 2004). This reduces competition, eases cultivation, and still provides more active roots to support soil biota.

Several organic growers have used weed fabric in the tree row for weed control where perennial weeds such as quackgrass (Agropyron repens) infest the orchard. The fabric has reduced competition with the trees, but a reservoir of the weed remains in the tree alley, which is aggressively mowed. However, Neilsen et al. (2003) found that black geotextile fabric led to a decline in soil quality and tree performance relative to other mulches. This was, in part, the result of elevated soil temperatures under the fabric (up to $10{ }^{\circ} \mathrm{C}$ ). Under the organic standards, plastic mulch must be removed before degradation in the field, adding to the cost. A biodegradable, sprayable paper mulch was developed and tested by Hogue et al. (2003) at Agriculture and AgriFood Canada, Summerland, BC. It enhanced tree growth in most trials, 
but the bulky nature and expense has been a barrier to adoption. Other biodegradable film and paper mulches are being tested by Miles (2005) for use in vegetable crops, and these may have an application for organic orchards.

In a related experiment, a wood chip mulch led to as much as a fourfold increase in codling moth larval mortality from the application of entomopathogenic nematodes (Steinernema feltiae, S. carpocapse), because the mulch helped maintain the free water needed by the nematodes to survive and locate the target organism (Lacey et al., 2006). Additional control of this key pest would provide another economic benefit from mulch.

Rodents represent a major barrier to the use of mulches in an orchard floor management system. One of the primary reasons for the traditional practice of a bare ground weed strip in the tree row and a grass tree alley is to minimize rodent habitat (Sullivan and Hogue, 1987). Any cover will encourage voles (Microtus spp.), because it provides protection from predators and may provide a food source. Gophers (Thomomys talpoides) prefer to feed on the fleshy roots of leguminous plants. We are testing candidate living mulch species that might prove repellent to rodents (Sullivan, 2006). For example, sweet woodruff (Galium odoratum) contains coumarin in its tissue, and initial field measurements showed lower vole activity in those plots than in legume plots (data not shown). Growers report that mint also repels voles, but this has not been confirmed. We and others have consistently observed the absence of voles in the wood chip mulch.

\section{SUMMARY}

As the area of organic orchards expands as a result of increased market demand and concern for environmental stewardship, more research and innovation will be focused on improving weed control and tree nutrition to address production constraints and costs as well as to enhance the agroecosystem. Currently, no single practice provides satisfactory weed control, and most growers rely on increasingly expensive inputs of organic amendments to provide $\mathrm{N}$ and other nutrients. Finding practices and strategies that can simultaneously address these two production issues, and possibly others (e.g., water conservation, pest biological control), will represent a major improvement for organic orchards. The principles of minimizing soil disturbance, filling vacant ecological niches, and enhancing soil biota are useful in directing ongoing research in orchard floor management to achieve the goal of sustainability, and mulches are one option to consider.

\section{Literature Cited}

Bauman, Y., B. Doppelt, S. Mazze, and E. Wolf. 2006. Impacts of climate change on Washing- ton's economy. Publication 07-01-010. Washington St. Dept. Ecology, Olympia, WA.

Baxter, P. 1970. Orchard soil management trials. 1. Effect of a weed-free or straw mulched strip on the growth and yield of young fruit trees. Aust. J. Exp. Agr. Anim. Husb. 10:467-473.

Cambardella, C.A. and E.T. Elliott. 1993. Carbon and nitrogen distribution in aggregates from cultivated and native grassland soils. Soil Sci. Soc. Amer. J. 57:1071-1076.

Cornwoman, M. and D. Granatstein. 1994. Organic apple production in Washington state. A 1994 survey of growers. Center for Sustaining Agriculture and Natural Resources, Washington State University, Wenatchee, WA.

Fiscus, D.A. and D.A. Neher. 2002. Distinguishing sensitivity of free-living soil nematode genera to physical and chemical disturbances. Ecol. Appl. 12:565-575.

Forge, T.A., E. Hogue, G. Neilsen, and D. Neilsen. 2003. Effects of organic mulches on soil microfauna in the root zone of apple: Implications for nutrient fluxes and functional diversity of the soil food web. Appl. Soil Ecol. 22:39-54.

Forge, T.A., R.E. Ingham, D. Kaufman, and J.N. Pinkerton. 2000. Population growth of Pratylenchus penetrans on winter cover crops grown in the Pacific Northwest. J. Nematol. 32:42-51.

Glover, J., H. Hinman, J. Reganold, and P. Andrews. 2002. A cost of production analysis of conventional vs. integrated vs. organic apple production systems. XB1041. Agricultural Research Center, Washington State University, Pullman, WA.

Granatstein, D. 2003. Organic tree fruit research needs for Washington state. Center for Sustaining Agriculture and Natural Resources, Washington Statue University, Wenatchee, WA, 24 Apr. 2007. <http://organic.tfrec.wsu.edu/ OrganicIFP/OrganicFruitProduction/Organic\% 20TF\%20Research\%20Summary\%20Sept03. pdf $>$.

Granatstein, D., E. Kirby, and C. Feise. 2006. Estimated Washington organic tree fruit acreage and price trends-2005. Center for Sustaining Agriculture and Natural Resources, Washington State University, Wenatchee, WA, 24 Apr. 2007. <http://organic.tfrec.wsu.edu/ OrganicStats/WAOrgTreeFruit05.pdf>.

Granatstein, D., E. Kirby, and L. VanWechel. 2003. Availability of mulch material for orchards in central Washington-2002. Center for Sustaining Agriculture and Natural Resources, Washington State University, Wenatchee, WA. 24 Apr. 2007. <http://organic.tfrec.wsu. edu/OrganicIFP/OrchardFloorManagement/ Availability $\% 20 \mathrm{of} \% 20$ Mulch.pdf $>$.

Granatstein, D., K. Mullinix, E. Kirby, and M. Brockington. 2005. Integrated multiple mulch trial progress report-2005. Center for Sustaining Agriculture and Natural Resources, Washington State University, Wenatchee, WA. 24 Apr. 2007. <http://organic.tfrec.wsu. edu/OrganicIFP/OrchardFloorManagement/ IMM_Progress_Report_2005.pdf>.

Gu, Y.H. and M. Mazzola. 2003. Modification of fluorescent pseudomonad community and control of apple replant disease induced in a wheat cultivar-specific manner. Appl. Soil Ecol. 24: $57-72$.

Hogue, E.J. and G.H. Neilsen. 1987. Orchard floor vegetation management. Hort. Rev. (Amer. Soc. Hort. Sci.) 9:377-430.

Hogue, E.J., G. Neilsen, T. Forge, and D. Neilsen. 2003. Use of a spray-on mulch of waste paper fiber in integrated fruit production, p. 883-894. In: Proc. 2nd Canadian Organic Residuals
Recycling Conference, Penticton, B.C., Apr. 23-26, 2003.

Lacey, L., D. Granatstein, S.P. Arthurs, H. Headrick, and R. Fritts Jr 2006. Use of entomopathogenic nematodes (Steinernematidae) in conjunction with mulches for control of overwintering codling moth (Lepidoptera: Tortricidae). J. Entomol. Sci. 41:107-119.

Liang, W. and M. Huang. 1994. Influence of citrus orchard ground cover plants on arthropod communities in China: A review. Agr. Ecosyst. Environ. 50:29-37.

Marsh, K.B., M.J. Daly, and T.P. McCarthy. 1996. The effect of understory management on soil fertility, tree nutrition, fruit production and apple fruit quality. Biol. Agr. Hort. 13:161173.

Merwin, I.A. 1995. IPM strategies for orchard soils: Groundcover management versus weed control. Proc. New England Fruit Meetings 101:43-49.

Merwin, I.A. and J.A. Ray. 1997. Spatial and temporal factors in weed interference with newly planted apple trees. HortScience 32:633-637.

Merwin, I.A. and J.A. Ray. 1999. Orchard groundcover management systems affect meadow vole populations and damage to apple trees. HortScience 34:271-274.

Merwin, I.A. and W.C. Stiles. 1994. Orchard groundcover management impacts on apple tree growth and yield, and nutrient availability and uptake. J. Amer. Soc. Hort. Sci. 119:209215.

Meyer, J.R., E.I. Zehr, R.L. Meagher, Jr., and S.K. Salvo. 1992. Survival and growth of peach trees and pest populations in orchard plots managed with experimental ground covers. Agr. Ecosyst. Environ. 41:353-363.

Miles, C. 2005. Alternatives to plastic mulch progress report. Center for Sustaining Agriculture and Natural Resources, Washington State University, Vancouver, WA. 24 Apr. 2007. <http:// agsyst.wsu.edu/AltMulch.htm\#2005>.

Neilsen, G.H., E.J. Hogue, T. Froge, and D. Neilsen. 2003. Mulches and biosolids affect vigor, yield, and leaf nutrition of fertigated high density apple. HortScience 38:41-45.

Oliveira, M.T. and I.A. Merwin. 2001. Soil physical conditions in a New York orchard after eight years under different groundcover management systems. Plant Soil 234:233237.

Rovira, A.D., L.F. Elliott, and R.J. Cook. 1990. The impact of cropping systems on rhizosphere organisms affecting plant health, p. 389-436. In: J.M. Lynch (ed.). The rhizosphere. Wiley, New York.

Sanchez, J.E., C.E. Edson, G.W. Bird, M.E. Whalon, T.C. Wilson, R.R. Harwood, K. Kizilkaya, J.E. Nugent, W. Klein, A. Middleton, T.L. Loudon, D.R. Mutch, and J. Scrimger. 2003. Orchard floor and nitrogen management influences soil and water quality and tart cherry yields. J. Amer. Soc. Hort. Sci. 128:277-284.

Schmid, A., F. Weibel, P. Allemann, and D. Santini. 2004. The FiBL sandwich system, p. 41-42. In: A. Haseli (ed.). Tagungsband zur FiBL Bioobstbautagung 28.01.2004. FiBL, Frick, Switzerland.

Six, J., E.T. Elliott, K. Paustian, and J.W. Doran. 1998. Aggregation and soil organic matter accumulation in cultivated and native grassland soils. Soil Sci. Soc. Amer. J. 62:1367-1377.

Stork, P.R. and P.H. Jerie. 2003. Initial studies of the growth, nitrogen sequestering, and dewatering potential of perennial grass selections 
for use as nitrogen catch crops in orchards. Aust. J. Agr. Res. 54:27-37.

Sullivan, T.P. 2006. Vole populations, tree fruit orchards, and living mulches. Project report. Applied Mammal Research Institute, Summerland, BC. 24 Apr. 2007. <http://organic.tfrec. wsu.edu/OrganicIFP/OrchardFloorManagement/ Voles_Orchards_Mulches_Report_2006.pdf>.

Sullivan, T.P. and E.J. Hogue. 1987. Influence of orchard floor management on vole and pocket gopher populations and damage in apple orchards. J. Amer. Soc. Hort. Sci. 112:971977.

Tedders, W.L. 1983. Insect management in deciduous orchard ecosystems: Habitat manipulation. Environ. Manage. 7:29-34.

Thompson, D.Q. 1965. Food preferences of the meadow vole (Microtus pennyslvanicus) in relation to habitat affinities. Amer. Midland Naturalist 74:76-86.

Wardle, D.A., G.W. Yeates, K.I. Bonner, K.S. Nicholson, and R.N. Wilson. 2001. Impacts of ground vegetation management strategies in a kiwifruit orchard on the composition and functioning of the soil biota. Soil Biol. Biochem. 33:893-905.

Yao, S., I.A. Merwin, G.W. Bird, G.S. Abawi, and J.E. Thies. 2005. Orchard floor management practices that maintain vegetative or biomass groundcover stimulate soil microbial activity and alter soil microbial community composition. Plant Soil 271:377389 . 